\title{
Fertilizer shanks to promote soil decompaction in the seeding operation
}

\section{Marta Sandra Drescher ${ }^{I}$ Dalvan José Reinert ${ }^{\mathrm{II}^{*}}$ José Eloir Denardin $^{\mathrm{III}}$ Paulo Ivonir Gubiani ${ }^{\mathrm{II}}$ Antônio Faganello ${ }^{\text {III }}$ Bernardo Rodrigues da Silva ${ }^{I I}$ Maísa Carina Zardin ${ }^{\text {II }}$}

IUniversidade Estadual do Rio Grande do Sul (UERGS), São Luiz Gonzaga, RS, Brasil.

"Departamento de Solos, Centro de Ciências Rurais (CCR), Universidade Federal de Santa Maria (UFSM), 97105-900, Santa Maria, RS, Brasil. E-mail: dalvan@ufsm.br. "Corresponding author.

IIIEmpresa Brasileira de Pesquisa Agropecuária (EMBRAPA), Passo Fundo, RS, Brasil.

ABSTRACT: Intensification of soil compaction process under no-tillage (NT) is motivating the search for alternatives to mitigate soil compaction state. This study evaluated changes in soil physical and hydraulic properties caused by seeder with fertilizer shanks at different depths compared with the double discs lagged seeder, to investigate the possibility of soil decompaction by sowing under NT in southern Brazil. The study was conducted in a clayed Oxisol, for 27 years under NT. Treatments were three planting mechanisms: $S_{01}:$ cutting disc combined with shank acting to $0.10 \mathrm{~m}$ depth; $S_{0.15 \mathrm{~m}}$ : cutting disc combined with shank acting to $0.15 \mathrm{~m}$ depth and, $D_{0.07 \mathrm{~m}}$ : double discs lagged acting to $0.07 \mathrm{~m}$ depth in an experimental randomized block design with four replications. We evaluated the soil mechanical resistance, water infiltration rate, soil bulk density, pore size distribution and unsaturated hydraulic conductivity. Results indicated that the use of seeder with fertilizer shanks acting at $0.15 \mathrm{~m}$ deep promoted the soil decompaction by the reduction of penetration resistance and increase of porosity and unsaturated hydraulic conductivity. To have significant increase in water infiltration rate the fertilizer shanks of the seeder must be deepened to the lower limit of the compacted surface layer.

Key words: soil management, mechanical decompaction, soil structure recovery.

Haste sulcadora para descompactação do solo na operação de semeadura

RESUMO: A intensificação do processo de compactação do solo em sistema plantio direto (SPD) motiva a procura por alternativas para atenuação do estado de compactação do solo. Esse trabalho objetiva avaliar modificações em propriedades físico-hídricas do solo originadas por semeadoras equipadas com hastes sulcadoras que atuam em diferentes profundidades, em comparação à semeadora com discos duplos defasados, para investigar a possibilidade de descompactação do solo na operação de semeadura em áreas sob SPD na região Sul do Brasil. O estudo foi realizado em Latossolo Vermelho Distrófico típico, de textura argilosa, há 27 anos sob SPD. Os tratamentos foram três mecanismos de semeadura: $H_{0,10 m:}$ disco de corte combinado com haste sulcadora atuando a 0,10m de profundidade; $H_{0,15 m}:$ disco de corte combinado com haste sulcadora atuando a 0,15m de profundidade; e $D_{0.7 m}$ : discos duplos defasados atuando a $0,07 \mathrm{~m}$ de profundidade, em delineamento experimental blocos ao acaso com quatro repetições. Avaliou-se a resistência mecânica à penetração, taxa de infiltração de água no solo, densidade do solo, distribuição do tamanho de poros e condutividade hidráulica do solo não saturado. Os resultados indicaram que a utilização de semeadora com haste sulcadora atuando a 0,15m promove a descompactação do solo através da redução da resistência mecânica do solo à penetração, aumento da porosidade e da condutividade hidráulica. Para que haja aumento significativo da infiltração de água no solo, a haste sulcadora da semeadora deve ser aprofundada até o limite inferior da camada superficial compactada.

Palavras-chave: manejo do solo, descompactação mecânica, estrutura do solo.

\section{INTRODUCTION}

No-tillage system (NTS) is defined as a complex of technological processes for agricultural production systems where soil mobilization occurs only in the sowing line, maintenance of soil cover and plant species diversification, through rotation and/or intercropping cultures (DENARDIN et al., 2011). However, of the 32 million hectares managed under no-tillage in Brazil, no more than 2.7 million hectares are cultivated in the winter season, so with potential to meet the crop rotation precepts and soil coverage of the management system (DIAS, 2014). In addition, the monoculture of soybean / fallow and succession such as soybean / winter maize or soybean / millet, which occupy the vast majority of areas managed under no-tillage in Brazil, are not a crop rotation system, required as one of the precepts of the NTS (DIAS, 2014). Associated with the partial implementation of the NTS precepts the use of seeders devoid of fertilizer shanks with deposition of fertilizer on the surface or in the surface layer of soil with intensive grazing and increasing agricultural machinery traffic frequency has led to the formation of a layer of more compacted soil, between 0.07 and $0.15 \mathrm{~m}$, which can hinder or even prevent root growth (SUZUKI et al., 2008; DRESCHER et al., 2011). In this layer the compaction rate caused by the 
successive pressure applied to the ground is greater than the decompression rate promoted by agents that act more effectively in soil surface, thus implying a progressive increase in the degree of compaction.

Soil decompaction favors the initial development of cultivated plant roots, its growth to deeper layers and subsequent formation of biopores, which facilitate air and water flows in the soil (BRADY \& WEIL, 2013). As a strategy to decompact the soil, farmers make mechanical soil chiseling. As an immediate effect of this practice the compacted layer is broken and has an increase of surface roughness, with benefits to soil water infiltration rate, reduction of the bulk density and increasing porosity.

However, chiseling is an energy-intensive operation, requires investment to purchase ripper and implies changes in the management system (CHAMEN, 2015), in contrast to the provision of minimum soil mobilization implicit in the NTS. In addition, the change in soil properties promoted by soil chiseling has presented short duration (DRESCHER et al., 2012; SILVA et al., 2012), often less than one year (ALVAREZ, et al., 2009).

As a result, soil chiseling may not be the best alternative of soil mechanical decompaction or to prevent it reaches critical levels of compaction. This is because the ordinary use of the chisel plowing may leave the soil more susceptible to a subsequent more intense compaction (CANARACHE et al., 2000), since the increase in time without revolving the soil under NT alters the bonding strength of the soil aggregated particles, increasing the strength of the structure to forces applied to the soil (REICHERT et al., 2010). Thus, there is need to find alternative solutions for soil decompaction.

Use of seeders equipped with furrow openers type fertilizer shanks, which act in sequence to the cutting discs is an option to be tested for soil decompaction in the row. This practice enables the decompaction located only in the vicinity of the site of deposition of the seed, which can be sufficient to improve the physical properties of soil, eliminating all mechanical chisel plowing for whole soil of roots growing layer.

However, the vast majority of seeders seed drills, have angle and dimensions that limit their action to depths greater than $0.10 \mathrm{~m}$. Fertilizer shanks with narrow tips, which equip most seeders used in no-tillage have limited capacity to promote the breakdown of cross-sectional area of the groove and mobilize soil (HEMMAT \& ADAMCHUK, 2008), restricting their ability to decompress the ground managed under NTS. For seeders equipped with furrow openers at different depths of action, little is known about the changes in physical and hydraulic properties of the soil. Thus, the present study aimed to evaluate the changes in physical and hydraulic properties of the soil with seeder equipped with fertilizer shanks acting at different depths compared to seeder with double discs lagged in order to investigate the possibility of reducing the state of soil compaction by sowing operation in areas managed under no-tillage system in southern Brazil.

\section{MATERIALS AND METHODS}

The study was conducted in the experimental field of the National Wheat Research Center - Embrapa Trigo, located in the municipality of Coxilha - RS, in a typical dystrophic red Latossol (EMBRAPA, 2013), clayey, with an average of $55 \%$ clay, $23 \%$ silt and $22 \%$ sand, at soil surface. The climate, according to Köppen classification, is Cfa - humid subtropical climate with rainfall well distributed throughout the year.

The study was conducted in the summer field season of 2012/2013 using an experiment established in 2009 in an area used for grain production managed under NTS for 27 years. The experiment crop sequence was: corn (2009/2010), wheat (2010), soybean (2010/2011), rye (2011), maize (2011/2012), wheat (2012) and soybean (2012/2013). The winter crops were sown with dual disc lagged with spacing of $0.17 \mathrm{~m}$, while the summer crops were sown with three compositions sowing mechanisms, which constituted the treatments of this study:

$\mathrm{S}_{0.10 \mathrm{~m}}$ : cutting disc combined with shank acting to $0.10 \mathrm{~m}$ deep;

$\mathrm{S}_{0.15 \mathrm{~m}}$ : cutting disc combined with shank acting to $0.15 \mathrm{~m}$ deep; and

$\mathrm{D}_{0.07 \mathrm{~m}}$ : double discs lagged acting to $0.07 \mathrm{~m}$ deep.

The shank used in no-till seeder has adjustable length depending on the desired depth of operation, up to $0.25 \mathrm{~m}$ depth; thickness of $0.01 \mathrm{~m}$, width $0.06 \mathrm{~m}$ and angle of attack to the ground equal $90^{\circ}$. The shank tip is incorporated into the body of the shank also having $0.01 \mathrm{~m}$ in thickness, with the front of the shank beveled and the angle of attack of $22.5^{\circ}$. The spacing between the shanks (sowing lines) was $0.35 \mathrm{~m}$ for the soybean crop and $0.70 \mathrm{~m}$ for the corn crop. The experiment was conducted in experimental design of randomized blocks with four replications, totaling thus 12 experimental units of $14.4 \mathrm{~m}^{2}(8 \mathrm{~m} \times 1.8 \mathrm{~m})$.

In December 2012 and April 2013 (beginning and end of the soybean crop cycle, respectively), the soil mechanical resistance to 
penetration (PR, $\mathrm{MPa}$ ) was measured in the field, using a georeferenced penetrometer PNT-2000, according to ASAE standards S 313.3 (ASABE, 2006). The rod, with conical tip of $30^{\circ}$ and conical area of $129 \mathrm{~mm}^{2}$, was inserted into the ground to penetration speed of approximately $2 \mathrm{~m} \mathrm{~min}^{-1}$, and PR data recorded every $0.01 \mathrm{~m}$ to $0.40 \mathrm{~m}$ depth. Measurements were carried out on the seeding line and $0.05,0.10$ and $0.20 \mathrm{~m}$ to the left and right, between the lines of sowing. At the time of PR measurements soil samples were collected to determine the gravimetric water content, 0.03 , $0.10,0.15,0.20,0.30$ and $0.40 \mathrm{~m}$ depth in three points of each experimental block.

The water infiltration rate in the soil was measured in March 2013, on the soybean seeding line, using infiltrometer of concentric rings with diameters of $0.20 \mathrm{~m}$ and $0.40 \mathrm{~m}$ for the inner and outer ring, respectively, both inserted in the soil to a depth of $0.15 \mathrm{~m}$, according to the methodology described by EMBRAPA (2011). A steady state of infiltration rate was assumed (SIR $\mathrm{mm} \mathrm{h}^{-1}$ ) with the value of final reading (at $2 \mathrm{~h}$ ) because at that time there was little variation in the rate of infiltration.

Soil samples with preserved structure were collected in May 2013, using stainless steel rings measuring $0.04 \mathrm{~m}$ high and $0,055 \mathrm{~m}$ in diameter, in soybean planting row in layers from 0 to $0.07 \mathrm{~m}, 0,07$ to $0.15 \mathrm{~m}$ and 0.15 to $0.25 \mathrm{~m}$. Samples were saturated in a tray, in which the high of water was gradually increased to the upper edge of the rings, for 48 hours, weighed, and carried to the sand column (REINERT \& REICHERT, 2006) for application of tensions ( $\Psi$, $\mathrm{kPa}$ ) of 1, 6 and $10 \mathrm{kPa}$, and Richards chambers for the application of $\Psi$ of 33 and $100 \mathrm{kPa}$ (KLUTE, 1986). In each $\Psi$, the samples were weighed to determine the volumetric water content $\left(\theta, \mathrm{cm}^{3} \mathrm{~cm}^{-3}\right)$. In $\Psi$ of 500 and $1500 \mathrm{kPa}$, the water content was estimated by dew point psychrometer - WP4, as described by KLEIN et al. (2006). The data $\psi$ and $\theta$ of each sample was adjusted by the VAN GENUCHTEN (1980) model according to the equation:

$$
\theta=\theta_{r}+\left(\theta_{s}-\theta_{r}\right)\left[1+(\alpha \psi)^{n}\right]^{-m}
$$

On what: $\theta, \theta_{\mathrm{r}}$ e $\theta_{\mathrm{s}}$ are the volumetric, residual and saturation water content, respectively, expressed in $\mathrm{cm}^{3} \mathrm{~cm}^{-3} ; \psi$ is water tension in soil, expressed in $\mathrm{kPa} ; \alpha\left(\mathrm{kPa}^{-1}\right), \mathrm{n}$ and $\mathrm{m}$ are empirical coefficients of the equation.

The $\theta$ s parameter was considered equal to the total porosity; the parameter $\mathrm{m}$ is restricted to the condition $\mathrm{m}=1-1 / \mathrm{n}$, in order to estimate the unsaturated hydraulic conductivity, by criteria suggested by MUALEM (1976); The $\theta \mathrm{r}, \alpha$ and $n$ parameters were estimated by regression analysis, using the proc NLIN procedure of SAS 9.2 (SAS INSTITUTE INC., 2010).

The hydraulic conductivity of the unsaturated soil $(\mathrm{K})$ was estimated by the theoretical model of Van Genuchten-Mualen as described in JONG VAN LIER et al. (2009):

$$
K=K_{s} S_{e}^{\gamma}\left[1-\left(1-S_{e}^{\frac{1}{m}}\right)^{m}\right]^{2}
$$

On what: $\mathrm{S}_{\mathrm{e}}$ is the effective saturation $(\theta$ $\theta \mathrm{r}) /(\theta \mathrm{s}-\theta \mathrm{r}) ; \gamma=0.5 ; \mathrm{Ks}$ is the hydraulic conductivity of saturated soil $\left(\mathrm{mm} \mathrm{h}^{-1}\right)$ measured in constant head permeameter (LIBARDI, 2012); and $\mathrm{m}$ is obtained from the equation (1).

The total porosity (Tp, $\left.\mathrm{m}^{3} \mathrm{~m}^{-3}\right)$, microporosity ( $\mathrm{Mi}, \mathrm{m}^{3} \mathrm{~m}^{-3}$ ), macroporosity ( $\mathrm{Ma}$, $\mathrm{m}^{3} \mathrm{~m}^{-3}$ ) and bulk density (BD, $\mathrm{Mg} \mathrm{\textrm {m } ^ { - 3 }}$ ) were determined by the method described in EMBRAPA (2011). Prior to analysis of variance, the variables were submitted to Lilliefors tests for normality and Cochran for homogeneity of variance. It was detected abnormal distribution of SIR, which was subjected to logarithmic transformation. When the analysis of variance was significant, the treatments were compared by Tukey test. All these tests were performed in statistical software Assistat 7.7 beta (SILVA, 2015) and evaluated to 5\% error probability.

\section{RESULTS AND DISCUSSION}

The use of fertilizer shanks $\left(\mathrm{S}_{0.10 \mathrm{~m}}\right.$ e $\left.\mathrm{S}_{0.15 \mathrm{~m}}\right)$ did not modify the BD compared to using only lagged Dual Discs $\left(\mathrm{D}_{0.07 \mathrm{~m}}\right)$, for all the evaluated soil layer (Table 1). In the layer of 0 to $0.07 \mathrm{~m}$ there were also no differences for Tp, Ma and Mi between treatments. This is because that the three seeding line preparation mechanisms $\left(\mathrm{S}_{0.10 \mathrm{~m}}, \mathrm{~S}_{0.15 \mathrm{~m}}\right.$ e $\left.\mathrm{D}_{0.07 \mathrm{~m}}\right)$ mobilized the soil layer from 0 to $0.07 \mathrm{~m}$. Furthermore, the higher root and the organic matter concentration at the soil surface promoted a greater biological activity and also intensity of wetting and drying cycles (BAVOSO et al., 2012), which contributed to soil decompaction.

Unlike, in the layer from 0.07 to $0.15 \mathrm{~m}$, the soil mobilization promoted by $\mathrm{S}_{0.15 \mathrm{~m}}$ increased Pt and Ma because $\mathrm{D}_{0.07 \mathrm{~m}}$ mechanism did not cause disturbance at this depth, and the soil disturbance promoted by $\mathrm{S}_{0.10 \mathrm{~m}}$ was not enough to promote decompaction higher than promoted by $\mathrm{D}_{0.07 \mathrm{~m}}$. This indicated that, in clayey Oxisol, compacted soil layer which is located between 0.07 and $0.15 \mathrm{~m}$, as seen 
Table 1 - Changes in soil bulk density, total porosity, macro and microporosity by seeding mechanisms, in layers from 0 to $0.07 \mathrm{~m}, 0.07$ to $0.15 \mathrm{~m}$ and 0.15 to $0.25 \mathrm{~m}$

\begin{tabular}{|c|c|c|c|c|c|}
\hline \multirow{2}{*}{ Soil properties } & \multirow{2}{*}{ Soil layer (m) } & & eeder $\mathrm{m}$ & & \multirow{2}{*}{ CV $(\%)$} \\
\hline & & $\mathrm{D}_{0.07 \mathrm{~m}}$ & $\mathrm{~S}_{0.10 \mathrm{~m}}$ & $\mathrm{~S}_{0.15 \mathrm{~m}}$ & \\
\hline \multirow{3}{*}{$\begin{array}{l}\text { Bulk density } \\
\left(\mathrm{Mg} \mathrm{m}^{-3}\right)\end{array}$} & 0 a 0.07 & $1.13^{\mathrm{ns}}$ & 1.14 & 1.11 & 5.9 \\
\hline & 0.07 a 0.15 & $1.46^{\mathrm{ns}}$ & 1.42 & 1.30 & 6.5 \\
\hline & 0.15 a 0.25 & $1.36^{\mathrm{ns}}$ & 1.32 & 1.28 & 4.3 \\
\hline \multirow{3}{*}{$\begin{array}{l}\text { Total porosity } \\
\left(\mathrm{m}^{3} \mathrm{~m}^{-3}\right)\end{array}$} & 0 a 0.07 & $0.61^{\mathrm{ns}}$ & 0.60 & 0.61 & 4.2 \\
\hline & 0.07 a 0.15 & $0.48^{*} \mathrm{~b}$ & $0.48 \mathrm{~b}$ & $0.52 \mathrm{a}$ & 4.4 \\
\hline & 0.15 a 0.25 & $0.51^{\mathrm{ns}}$ & 0.52 & 0.52 & 4.4 \\
\hline \multirow{3}{*}{$\begin{array}{l}\text { Microporosity } \\
\left(\mathrm{m}^{3} \mathrm{~m}^{-3}\right)\end{array}$} & 0 a 0.07 & $0.37^{\mathrm{ns}}$ & 0.23 & 0.39 & 6.2 \\
\hline & 0.07 a 0.15 & $0.40^{\text {ns }}$ & 0.40 & 0.42 & 3.6 \\
\hline & 0.15 a 0.25 & $0.44^{\mathrm{ns}}$ & 0.45 & 0.46 & 5.9 \\
\hline \multirow{3}{*}{$\begin{array}{l}\text { Macroporosity } \\
\left(\mathrm{m}^{3} \mathrm{~m}^{-3}\right)\end{array}$} & 0 a 0.07 & $0.23^{\mathrm{ns}}$ & 0.37 & 0.22 & 19.2 \\
\hline & 0.07 a 0.15 & $0.08^{*} \mathrm{~b}$ & $0.08 \mathrm{~b}$ & $0.10 \mathrm{a}$ & 13.4 \\
\hline & 0.15 a 0.25 & $0.07^{\mathrm{ns}}$ & 0.07 & 0.07 & 30.1 \\
\hline
\end{tabular}

*Values followed by the same letter on the line do not differ by Tukey test at $5 \%$ probability. $\mathrm{S}_{0.10 \mathrm{~m}}$ : cutting discs combined with fertilizer shanks acting to $0.10 \mathrm{~m}$ depth;

$\mathrm{S}_{0.15 \mathrm{~m}}$ : cutting discs combined with fertilizer shanks acting to $0.15 \mathrm{~m}$ depth;

$\mathrm{D}_{0.07 \mathrm{~m}}$ : double discs lagged acting to $0.07 \mathrm{~m}$ depth.

in several areas managed under no-tillage (SUZUKI et al, 2008;. DRESCHER et al., 2011), the deepening of fertilizer shanks up to $0.15 \mathrm{~m}$ is required when the sowing operation has decompaction as its purpose.

The PR was lower in the beginning of soybean cycle (Figure 1a); although, water content in the superficial layers of the soil was lower than at the end of the cultivation cycle. Both the beginning and end of the soybean cycle, figures $1 \mathrm{a}$ and $1 \mathrm{~b}$, shows that the PR along the sowing line did not exceed 2.0MPa, value often considered critical for root development of crops (COLLARES et al., 2006; REICHERT et al., 2009), up to 0.20m deep where sowing was done with $\mathrm{S}_{0.15 \mathrm{~m}}$. Furthermore, $\mathrm{PR}$ was higher than $3.0 \mathrm{MPa}$ in the layer between 0.10 and $0.15 \mathrm{~m}$ in places where seeding was carried out with $\mathrm{D}_{0.07 \mathrm{~m}}$. This result allowed to infer that when fertilizer shank used in the sowing operation was set to reach $0.15 \mathrm{~m}$ depth, it was efficient to break the cross-section of the groove area, decompacting the soil and forming a soil profile with less resistance to mechanical penetration along the seeding line.

Seeding mechanisms have also changed the estimated $\mathrm{K}$ (equation 2) at different water tensions $(10,33,100,500$ and $1000 \mathrm{kPa})$, in the layer 0 to 0.07 and 0.07 to $0.15 \mathrm{~m}$ (Table 2 ). In the layer of 0 to $0.07 \mathrm{~m}$, both $\mathrm{S}_{0.10 \mathrm{~m}}$ and $\mathrm{S}_{0.15 \mathrm{~m}}$ promoted increased in $\mathrm{K}$ compared to $\mathrm{D}_{0.07 \mathrm{~m}}$. However, in the layer 0.07 to $0.15 \mathrm{~m}$, as similar to what was observed for $\mathrm{Pt}, \mathrm{Ma}$ and PR, only $\mathrm{S}_{0.15 \mathrm{~m}}$ was efficient to increase $\mathrm{K}$. The $\mathrm{K}$ reflects the physical condition of the soil as structure, porosity and presence of compacted layers, thus the benefits verified by the use of fertilizer shank $S_{015 \mathrm{~m}}$ on the distribution of pore size in no-tillage managed areas increased soil hydraulic conductivity at different water tensions, benefiting the soil water flows.

The increase in $\mathrm{K}$ by use of $\mathrm{S}_{0.15 \mathrm{~m}}$ reflected in increased of steady infiltration rate at $2 \mathrm{~h}$, which was two and a half times higher where sowing was carried out with $\mathrm{S}_{0.15 \mathrm{~m}}$ in relation to the use of $\mathrm{S}_{0.10}$ or $\mathrm{D}_{0.07 \mathrm{~m}}$ (Figure 2a). Consequently, the total infiltrated water, at the end of $0.5,1$ and 2 hours of evaluation, was always greater in the treatment $\mathrm{S}_{015 \mathrm{~m}}$ as compared to treatment $\mathrm{S}_{0.10 \mathrm{~m}}$ or $\mathrm{D}_{0.07 \mathrm{~m}}$ (Figure $2 \mathrm{~b}$ ). These results corroborated what VIZZOTTO (2014) reported, that after 180 minutes of infiltration was observed increments of $89.2 \%$ for infiltration rate and $69 \%$ for cumulative infiltration when fertilizer shanks was used as compared where only discs were used. However, in this study, the depth of shank action had more significant effect to increase water infiltration into the soil than the type of mechanism itself.

Compared to treatments $\mathrm{S}_{0.10 \mathrm{~m}}$ and $\mathrm{D}_{0.07 \mathrm{~m}}$, the treatment $\mathrm{S}_{0.15 \mathrm{~m}}$ reduced PR and increased Tp, $\mathrm{Ma}$ and $\mathrm{K}$ in greater depth, and increased SIR at $2 \mathrm{~h}$ and accumulated infiltration into the soil. From these results, it appears that the sowing operation can also perform the function of decompacting the topsoil, since the fertilizer shanks can operate to a depth of $0.15 \mathrm{~m}$. This suggested that tillage with fertilizer shanks in seeders can replace the tillage with tillers, when the objective is to decompact the topsoil. 


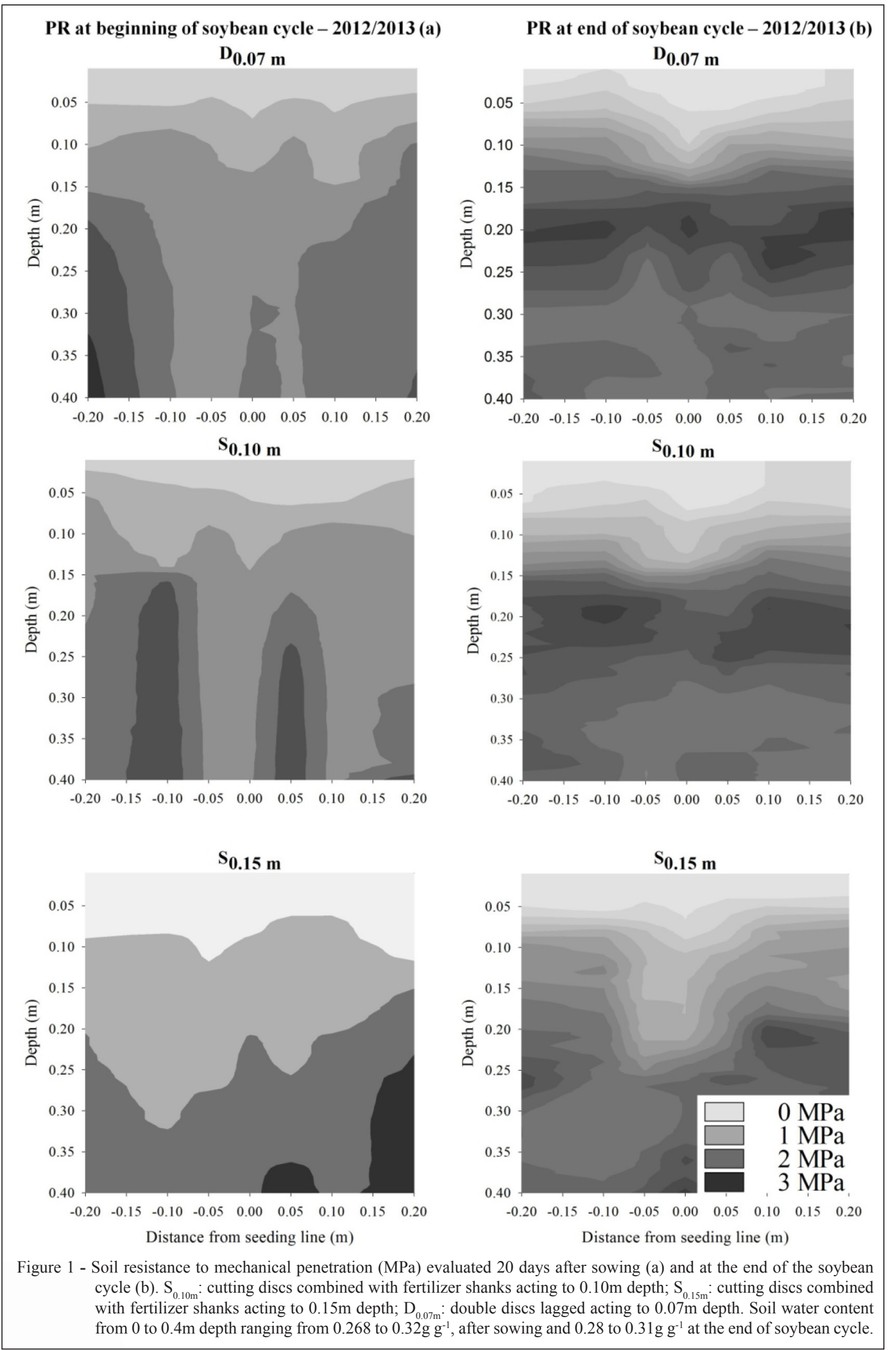

Ciência Rural, v.47, n.2, 2017. 
Table 2 - Changes in the hydraulic conductivity of the unsaturated soil (K) by seeding mechanisms in layers 0 to $0.07 \mathrm{~m}$. 0.07 to $0.15 \mathrm{~m}$ and 0.15 to $0.25 \mathrm{~m}$.

\begin{tabular}{|c|c|c|c|c|c|}
\hline \multirow{2}{*}{$\begin{array}{l}\text { Seeder } \\
\text { mechanisms }\end{array}$} & \multicolumn{5}{|c|}{ 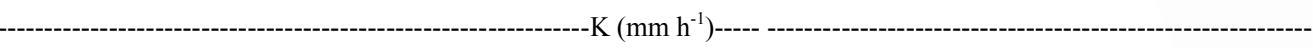 } \\
\hline & $10 \mathrm{kPa}$ & $33 \mathrm{kPa}$ & $100 \mathrm{kPa}$ & $500 \mathrm{kPa}$ & $1000 \mathrm{kPa}$ \\
\hline $\mathrm{D}_{0,07 \mathrm{~m}}$ & $49.13^{*} \mathrm{~b}$ & $39.48^{*} \mathrm{~b}$ & m------- & $7.29^{*} \mathrm{~b}$ & $5.66^{*} \mathrm{~b}$ \\
\hline $\mathrm{S}_{0.10 \mathrm{~m}}$ & $297.14 \mathrm{a}$ & $261.59 \mathrm{a}$ & $217.18 \mathrm{a}$ & $54.53 \mathrm{a}$ & $42.71 \mathrm{a}$ \\
\hline $\mathrm{S}_{0.15 \mathrm{~m}}$ & $242.75 \mathrm{a}$ & $202.90 \mathrm{ab}$ & $171.52 \mathrm{a}$ & $37.30 \mathrm{a}$ & $29.16 \mathrm{a}$ \\
\hline CV (\%) & 79.1 & 80.5 & 80.1 & 92.9 & 93.2 \\
\hline \multicolumn{6}{|c|}{ 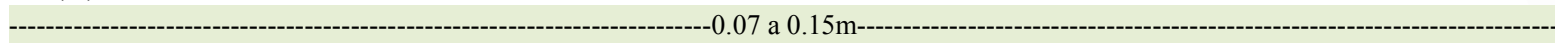 } \\
\hline $\mathrm{D}_{0.07 \mathrm{~m}}$ & $5.38 * \mathrm{~b}$ & $4.92{ }^{*} \mathrm{~b}$ & $4.36{ }^{*} \mathrm{~b}$ & $1.35^{*} \mathrm{ab}$ & $1.08^{*} \mathrm{ab}$ \\
\hline $\mathrm{S}_{0.10 \mathrm{~m}}$ & $1.95 \mathrm{~b}$ & $1.78 \mathrm{~b}$ & $1.60 \mathrm{~b}$ & $0.49 \mathrm{~b}$ & $0.39 \mathrm{~b}$ \\
\hline $\mathrm{S}_{0.15 \mathrm{~m}}$ & $38.31 \mathrm{a}$ & $32.64 \mathrm{a}$ & $28.43 \mathrm{a}$ & $6.21 \mathrm{a}$ & $4.94 \mathrm{a}$ \\
\hline $\mathrm{CV}(\%)$ & 140.3 & 142.5 & 140.7 & 135.8 & 135.9 \\
\hline \multicolumn{6}{|c|}{ } \\
\hline $\mathrm{D}_{0.07 \mathrm{~m}}$ & $3.40^{\text {ns }}$ & $3.02^{\text {ns }}$ & $2.60^{\text {ns }}$ & $0.75^{\text {ns }}$ & $0.59^{\mathrm{ns}}$ \\
\hline $\mathrm{S}_{0.10 \mathrm{~m}}$ & 2.53 & 2.25 & 1.95 & 0.53 & 0.42 \\
\hline $\mathrm{S}_{0.15 \mathrm{~m}}$ & 9.22 & 7.31 & 6.63 & 1.48 & 1.17 \\
\hline CV (\%) & 102.1 & 94.4 & 97.5 & 74.3 & 74.2 \\
\hline
\end{tabular}

*Values followed by the same letter on the column do not differ by Tukey test at $5 \%$ probability.

$\mathrm{S}_{0.10 \mathrm{~m}}$ : cutting discs combined with fertilizer shanks acting to $0.10 \mathrm{~m}$ depth;

$\mathrm{S}_{0.15 \mathrm{~m}}$ : cutting discs combined with fertilizer shanks acting to $0.15 \mathrm{~m}$ depth;

$\mathrm{D}_{0.07 \mathrm{~m}}$ : double discs lagged acting to $0.07 \mathrm{~m}$ depth.

\section{CONCLUSION}

The use of seeders equipped with fertilizer shanks with action depth of $0.15 \mathrm{~m}$, promotes decompaction of the top soil under no-tillage, reducing soil mechanical resistance to penetration and increasing porosity and hydraulic conductivity.

To have a significant increase in water infiltration into the soil, the fertilizer shank of the seeder must be deepened to the lower limit of the compacted surface layer.

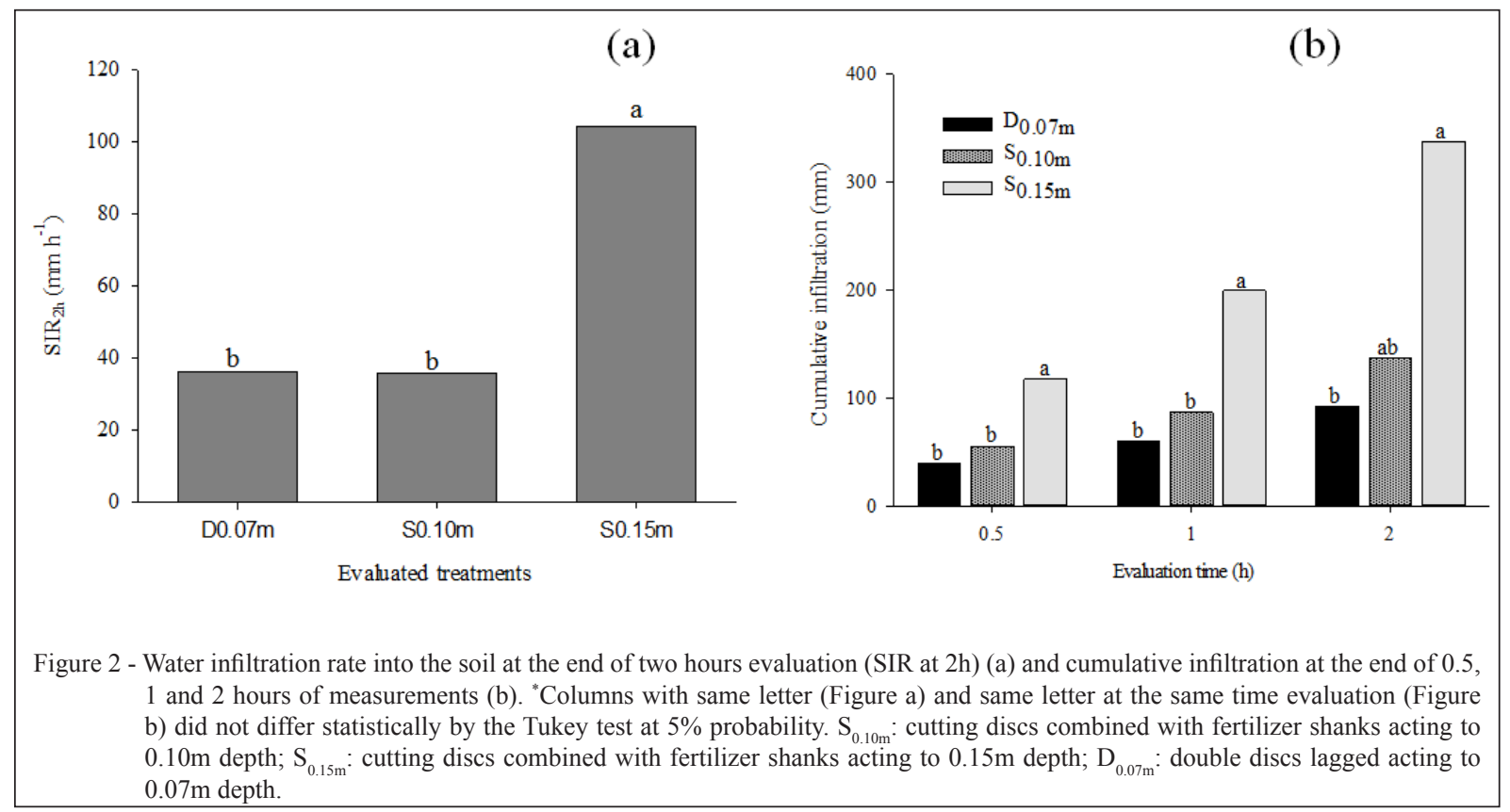

Ciência Rural, v.47, n.2, 2017. 


\section{ACKNOWLEDGEMENTS}

We would like to thank the financial support of the Conselho Nacional de Desenvolvimento Científico e Tecnológico (CNPq/Brasil) and Coordenação de Aperfeiçoamento de Pessoal de Nível Superior (CAPES)

\section{REFERENCES}

ÁLVAREZ, C.R. et al. Decompaction of no-tillage soils: effects on soil properties and crops. Ciencia del Suelo, v.27, p.159-169, 2009. Available from: <http://www.scielo.org.ar/pdf/cds/v27n2/ v27n2a02.pdf $>$. Accessed: Nov. 18, 2015.

ASABE (AMERICAN SOCIETY OF AGRICULTURAL AND BIOLOGICAL ENGINEERS). Soil cone penetrometer. St. Joseph: ASABE, 2006. ASAE standard S313.3. Available from: <https://elibrary.asabe.org/standards.asp $>$. Accessed: Nov. 15, 2015.

BAVOSO, M.A. et al. Physical resilience of two red oxisols under notillage. Revista Brasileira de Ciência do Solo, v.36, p.18921904, 2012. Available from: <http://www.redalyc.org/articulo. oa? $\mathrm{id}=180225136017>$. Accessed: Nov. 12, 2015.

BRADY, N.C.; WEIL, R.R. Elementos da natureza e propriedades dos solos. 3.ed. Porto Alegre: Bookman, 2013. 686p

CANARACHE, A. et al. Compressibility of soils in a long term field experiment with intensive deep ripping in Romania. Soil and Tillage Research, v.56, p.185-196, 2000. Available from: <http:// dx.doi.org/10.1016/S0167-1987(00)00143-4>. Accessed: Nov. 21, 2015. doi: 10.1016/S0167-1987(00)00143-4.

CHAMEN, T.W.C. et al. Mitigating arable soil compaction: a review and analysis of available cost and benefit data. Soil and Tillage Research, v.146, p.10-25, 2015. Available from: <http:/ dx.doi.org/10.1016/j.still.2014.09.011>. Accessed: Nov. 06, 2015. doi: 10.1016/j.still.2014.09.011.

COLLARES, G.L. et al. Soil physical quality on black beans yield in an Alfisol. Pesquisa Agropecuária Brasileira, v.41, p.16631674, 2006. Available from: <http://dx.doi.org/10.1590/S0100204X2006001100013>. Accessed: Oct. 06, 2015. doi: 10.1590/ S0100-204X2006001100013.

DENARDIN, J.E. et al. 15 de abril dia nacional da conservação do solo: a agricultura desenvolvida no Brasil é conservacionista ou não? Boletim Informativo da Sociedade Brasileira de Ciência do Solo, v.36, p.10-15, 2011. Available from: <http:// www.alice.cnptia.embrapa.br/handle/doc/903745>. Accessed: Nov. 06, 2015.

DIAS, C. Simplificação do plantio direto reduz eficiência da lavoura. Portal de Notícias Embrapa. 18 de julho de 2014. Available from: <https://www.embrapa.br/busca-de-noticias/-/ noticia/1909275/simplificacao-do-plantio-direto-reduz-eficienciada-lavoura $>$. Accessed: Feb. 12, 2015.

DRESCHER, M.S. et al. Persistence of mechanical interventions effect for soil decompaction in no-tillage systems. Revista Brasileira de Ciência do Solo, v.35, p.1713-1722, 2011. Available from: <http://www.redalyc.org/articulo oa?id=180221126026>. Accessed: Feb. 08, 2015. doi: 10.1590/ S010006832011000500026.

DRESCHER, M.S. et al. Penetration resistance and soybean yield after mechanical intervention on an oxisol under tillage. Revista Brasileira de Ciência do Solo, v.36, p.1836-1844, 2012. Available from: <http://dx.doi.org/10.1590/S010006832012000600018>. Accessed: Nov. 08, 2015. doi: 10.1590/ S010006832012000600018.

EMBRAPA (EMPRESA BRASILEIRA DE PESQUISA AGROPECUÁRIA). Centro Nacional de Pesquisa de Solos (Rio de Janeiro, RJ). Manual de métodos de análise de solo. Dados eletrônicos: 2.ed. Rio de Janeiro: Embrapa Solos, 2011. 230p.

EMBRAPA (EMPRESA BRASILEIRA DE PESQUISA AGROPECUÁRIA). Centro Nacional de Pesquisa de Solos. Sistema brasileiro de classificação de solos. Rio de Janeiro, 2013. 353p.

JONG VAN LIER, Q. de et al. Modeling of transpiration reduction in van Genuchten-Mualem type soils. Water Resources Research, v.45, p.1-9, 2009. Available from: <http://onlinelibrary.wiley.com/ doi/10.1029/2008WR006938/full>. Accessed: Nov. 28, 2015. doi: 10.1029/2008WR006938.

HEMMAT, A.; ADAMACHUK, V.I. Sensor systems for measuring soil compaction: review and analysis. Computer and Electronics in Agriculture, v.63, p.89-103, 2008. Available from: <http:// dx.doi.org/10.1016/j.compag.2008.03.001>. Accessed: Feb. 28, 2015. doi: 10.1016/j.compag.2008.03.001

KLEIN, V.A. et al. Available water in a clayey Oxisol and physiological wilting of crops. Revista Brasileira de Engenharia Agrícola e Ambiental, v.10, p.646-650, 2006. Available from: <http://dx.doi.org/10.1590/S141543662006000300016>. Accessed: Apr. 28, 2015. doi: 10.1590/ S1415-43662006000300016.

KLUTE, A. Water retention: laboratory methods. In: BLACK, C.A (Ed.). Methods of soil analysis. I. Physical and mineralogical methods. Madison: American Society of Agronomy, Soil Science Society of America, 1986. p.635-662.

LIBARDI, P.L. Dinâmica da água no solo. 2.ed. São Paulo: Edusp, 2012. 352p.

MUALEM, Y. A new model for predicting the hydraulic conductivity of unsaturated porous media. Water Resources Research, v.12, p.512-522, 1976. Available from: <http:// onlinelibrary.wiley.com/doi/10.1029/WR012i003p00513/epdf>. Accessed: Apr. 16, 2015. doi: 10.1029/WR012i003p00513.

REICHERT, J.M. et al. Temporal variation of soil physical properties and root growth of black beans in four management systems. Pesquisa Agropecuária Brasileira, v.44, p.310319, 2009. Available from: <http://dx.doi.org/10.1590/S0100204X2009000300013>. Accessed: Nov. 24, 2015. doi: 10.1590/ S0100-204X2009000300013.

REICHERT, J.M. et al. Mecânica do solo. In: Van LIER, Q.J. (Ed.). Física do solo. Viçosa, MG: SBCS, 2010. p.29-102.

REINERT, D.J.; REICHERT, J.M. Use of sand column to measure soil water retention - prototypes and test. Ciência Rural, v.36, p.1931-1935, 2006. Available from: < http://dx.doi.org/10.1590/ 
S0103-84782006000600044>. Accessed: Oct. 24, 2015. doi: $10.1590 / \mathrm{S} 0103-84782006000600044$

SAS INSTITUTE INC. SAS/STAT ${ }^{\circledR}$ 9.22 user's guide. Cary, NC, 2010. 8445 p.

SILVA, F.A.S. ASSISTAT: Versão 7.7 beta (2015). Universidade Federal de Campina Grande, UFCG-Brasil. Available from: $<$ http://www.assistat.com/>. Accessed: May 20, 2015.

SILVA, S.G.C. et al. Temporary effect of chiseling on the compaction of a Rhodic Hapludox under no-tillage. Revista Brasileira de Ciência do Solo, v.36, p.547-555, 2012. Available from: <http:// dx.doi.org/10.1590/S0100-06832012000200024>. Accessed: May 24, 2015. doi: 10.1590/S0100-06832012000200024.

SUZUKI, L.E.A.S. et al. Estimating soil susceptibility to compaction and load support capacity based on physical parameters of soils from Rio Grande do Sul state. Revista Brasileira de Ciência do Solo, v.32, p.963-973, 2008. Available from: <http://dx.doi.org/10.1590/S010006832008000300006>. Accessed: May 05, 2015. doi: 10.1590/ S0100-06832008000300006.

VAN GENUCHTEN, M.Th. A closed-form equation for predicting the hydraulic conductivity of unsaturated soils. Soil Science Society of America Journal, v.44, n.5, p.892-898, 1980. Available from: <https://www.ars.usda.gov/arsuserfiles/20360500/ pdf pubs/P0682.pdf>. Accessed: Nov 05, 2015. doi: 10.2136/ sssaj1980.03615995004400050002x.

VIZZOTTO, V.R. Desempenho de mecanismos sulcadores em semeadora-adubadora sobre atributos físicos do solo em várzea no comportamento da soja (Glicine Max I). 2014. 79f. Tese (Doutorado em Engenharia Agrícola) - Universidade Federal de Santa Maria, Santa Maria, RS. 